Article

\title{
Does Resident Participation in an Urban Regeneration Project Improve Neighborhood Satisfaction: A Case Study of "Amichojang" in Busan, South Korea
}

\author{
Eunae Jin ${ }^{1}$, Woojong Lee ${ }^{2}$ and Danya Kim ${ }^{3, *}$ \\ 1 Global City Research Center, Gachon University, Seongnamdaero 1324, Korea; sunrising81@daum.net \\ 2 Department of Urban Planning, College of Engineering, Gachon University, Seongnamdaero 1324, Korea; \\ woolee@gachon.ac.kr \\ 3 Graduate School of Tourism, Kyung Hee University, Seoul 02447, Korea \\ * Correspondence: aesthetic82@gmail.com; Tel.: +82-10-7187-7822
}

Received: 10 September 2018; Accepted: 8 October 2018; Published: 18 October 2018

\begin{abstract}
One of the keys to successfully facilitating urban regeneration projects is to encourage resident participation, because participation produces more than just outcomes. However, few studies have examined whether the residents' participation in urban regeneration projects also increases residents' neighborhood satisfaction. Seeking to address this gap, our study examines the relationship between urban regeneration projects and residents' satisfaction, focusing on 'Amichojang' in Busan, South Korea. We collect 292 valid survey data and then geocode them based on their specific home address to consider spatial characteristics of their residential locations. We also employ an ordered probit model to account for our dependent variable measured as a five-point Likert scale. Our empirical results show that resident participation in urban regeneration projects is positively associated with improvement of neighborhood satisfaction. This result suggests that encouraging local resident participation in urban regeneration projects is significant for the success of these projects. However, there exist gender and age differences in the relationship between participation and neighborhood satisfaction. Therefore, various programs that can encourage more participation in urban regeneration projects should be designed for different demographic groups.
\end{abstract}

Keywords: urban regeneration; resident participation; neighborhood satisfaction; Amichojang; South Korea

\section{Introduction}

Urban areas are complex and dynamic systems. Planners and policy makers have dealt with these complicated urban systems to improve physical, social, environmental, and economic conditions through a variety of development projects. For example, they have invested a massive amount of money in infrastructure such as expansion of highways and transportation networks, new housing, and establishment of commercial districts. However, most urban development projects have historically focused on physical reconstruction and economic growth, thus neglected the values of community identity and cultural heritage. These massive urban transformation and renewal projects have destroyed people's sense of community identity, uniqueness, and distinctiveness [1]. As a result, the intangible assets of communities have disappeared, causing a number of urban problems such as displacement and gentrification of local inhabitants.

Urban regeneration has emerged as an alternative to urban renewal that highlights harmony between "constant" and "changing" elements of people and events in local communities [2]. 
The primary objective of urban regeneration is to address the complex urban dynamics and their problems by improving the economic, physical, social, and environmental conditions of an area that has been subject to change. Hence, these aspects of urban regeneration project are significantly different from simple physical redevelopment and reconstruction projects [3]. This is mostly because of a high degree of complexity and uncertainty in urban regeneration [4].

Roberts [4] (p. 18) defined urban regeneration as "comprehensive and integrated vision and action which seeks to resolve urban problems and bring about a lasting improvement in the economic, physical, social and environmental condition of an area that has been subject to change or offers opportunities for improvement". Moreover, other scholars have argued that it aims to transform the nature of communities by involving the local inhabitants and various stakeholders $[5,6]$. In order to achieve a number of objectives during an urban regeneration project, community participation, and bottom-up approaches are necessary in local areas. This also reinforces the sense of community, solidarity between community members, identity of the neighborhood, and residents' feelings of belonging within the community. Scholars have argued that this paradigm shift from physical redevelopment to urban regeneration for sustainable community development is to enhance residents' subjective well-being, quality of life, and happiness [6].

Despite the academic and practical importance of urban regeneration projects, surprisingly, scholars have not paid much attention to the direct effects of urban regeneration projects on the residents' satisfaction. This may be because many previous studies examining the impact of urban regeneration projects have focused on the formation of social capital and other intangible assets as an output of urban regeneration. As a result, there is no evidence of social capital and intangible assets being directly related to resident satisfaction or happiness. As of now, there is still little is known about whether or not urban regeneration projects improve the quality of life of residents and social values of local communities. We only know that urban regeneration projects increase social capital measured by networks, trust, and reciprocity between community members. Scholars may assume that the improvement of social capital can increase residents' neighborhood satisfaction. However, again, we are not sure whether urban regeneration projects directly improve residents' neighborhood satisfaction.

It has been argued that one of the most important elements in urban regeneration projects is the participation of local residents [7]. This is because informal opportunities for participation can become more and more institutionalized, leading to them becoming a key factor in the design and implementation of urban regeneration policies. In spite of the importance of participation, few studies have examined whether the residents' participation in urban regeneration projects increases residents' neighborhood satisfaction. Therefore, our understanding of the impacts of urban regeneration projects is limited. Seeking to address this gap, our study examines the relationship between urban regeneration projects and residents' satisfaction.

Our study area is "Amichojang" in Busan, South Korea, where an urban regeneration project has been implemented since 2013. We collect survey data based on sophistically designed questionnaires. Using ordered probit models, we examine how resident participation on the urban regeneration project affects neighborhood satisfaction. It is expected that our research will suggest important policy directions for sustainable urban regeneration projects.

The rest of the paper is organized as follows. In the next section, we go through the previous research relevant to the impacts of urban regeneration projects and residential satisfaction. Then, we introduce Korean regeneration projects in Section 3. In Section 4, we introduce our study area, and then describe our analytic framework and data. Section 5 presents the empirical results. In the last section, we summarize and discuss our findings and suggest policy implications.

\section{Literature Review: Urban Regeneration, Participation, and Neighborhood Satisfaction}

Urban regeneration is the attempt to renew declining inner-city neighborhoods by improving the physical infrastructure and revitalizing local economies. The concept of urban regeneration can be 
interpreted in a variety of ways, especially depending on the development stage of the country. In the aftermath of the Second World War, many Western cities attempted to reduce poverty and deprivation through urban development policies including the provision of social housing, public infrastructure, and welfare support. However, in the 1960 's, poverty was still prevalent within inner-cities, and many urban neighborhoods struggled with high crime rates, unemployment, and higher levels of stress [8]. Planners and policy makers started to rethink traditional approaches towards urban development. As a result, in the 1970's, in Western cities, massive urban redevelopment and renewal projects decreased and urban regeneration emerged as an alternative to urban renewal [9].

The urban regeneration programs in the 1970's began to involve residents as the subjects of regeneration [10]. At that time, poverty was regarded as the fault of the poor themselves because they failed to achieve economic independence. This is because market-oriented approaches were the most common strategies to accomplish urban regeneration projects. Hence, local residents were largely excluded from the urban regeneration process until the 1980's. However, residents' participation has come to play a key role in urban regeneration since the late 1980's and early 1990's because market-based approaches have failed to improve the lives of the poor who live in inner-city neighborhoods. Scholars have argued that this failure was mostly due to the lack of resident participation [9].

It is claimed that resident participation in urban regeneration projects are more efficient and effective to accomplish the goal of the schemes because it helps to deal with the most important problems that local residents perceive [10]. Sometimes, local residents are better at coming up with new and innovative ideas to resolve the problems. Moreover, resident participation can prevent pre-existing neighborhood schemes from being ignored and strengthen the schemes by drawing them into the urban regeneration process [10]. Another advantage of resident participation in urban regeneration is the prevention of social exclusion that is highly associated with unemployment, poor skills, high crime, poor housing, and family breakdown. Healy [11] has pointed out that social networks, social capital, and residential participation can be efficient resources for enhancing urban regeneration and preventing social exclusion. With this perspective, numerous scholars have investigated how resident participation affects the success of urban regeneration $[8,10,12,13]$. This claim does not mean that the top-down approach driven by technical experts should be excluded in planning process. It means that the bottom-up process (increases in awareness of local residents and more participation in decision-making) should be harmonized with the top-down one by more communication and cooperation between planners, politicians, and residents [14,15].

General belief is that participation is a 'good thing' for urban regeneration projects. However, some scholars have pointed out that residents are frequently excluded in the decision-making process of urban regeneration [8,10]. Without the redistribution of power, Arnstein [16] argued that participation is an empty experience. In her seminal work 'A ladder of community participation', she stressed that participation is about power. She suggested a typology of eight levels of participation. The bottom two rungs (manipulation and therapy) describe non-participation, whereas the top three rungs (citizen control, delegated power, and partnership) mean increasing degrees of decision-making power. While this eight-rung ladder is simple, it helps to indicate that participation is not simple, but has significant graduation. This suggests an important implication that the degree of participation in urban regeneration projects should be continuously checked and evaluated during all project phases.

Putnam $[17,18]$ has argued that face-to-face contact with other stakeholders helps to form social capital because it increases trust in each other. Hence, participation and civic engagement are associated with social trust, social networks, and social capital. Fainstein [19] also stressed that the values of equity, diversity, and democracy may produce better outcomes for 'the just city'. She argued that powerless and marginalized groups in the community should be encouraged to participate in the decision-making process. In addition, scholars have argued that higher social capital generates higher satisfaction and quality of life. For example, social capital increases workers' job satisfaction [20], public health [21], and life satisfaction $[22,23]$. Nevertheless, the relationship between urban regeneration participation 
and neighborhood satisfaction is largely unexplored in urban regeneration research. More studies that examine how resident participation in urban regeneration projects affect neighborhood satisfaction are necessary for better understanding of the outcomes of urban regeneration projects and for suggesting more sustainable urban regeneration policies.

\section{Urban Regeneration Project in Korea}

Like many Western cities, social justice has been distinctive in the discourse and rhetoric of urban regeneration policy in Korea. Since the 1970's, most cities in Korea have experienced rapid economic growth and urban expansion, which has been led by the central government. The central government has controlled urban development until the early 1990's. Most of urban policy has focused on urban redevelopment for improving residential environments, reinforced by the 'Urban Redevelopment Act' legislated in 1976. In the 1980's, 'Temporary Measures for Residential Improvement for Low-Income Citizens' was legislated to implement residential improvement projects for low-income households. From the 1950's to the 1990's, redevelopment and reconstruction projects have been a main means for improving declined neighborhoods. However, this type of approach causes negative externalities such as gentrification resulting in the displacement of the original residents by higher income groups.

After the 2000's, the Korean government legislated the 'Maintenance and Improvement of Urban Areas and Dwelling Conditions for Residents Act' to improve the residential environment in the declined urban neighborhoods by integrating urban redevelopment, reconstruction, and regeneration projects. This approach is intended not only to overcome the negative effects of the previous approach, but also to maintain existing communities, strengthening neighborhood cohesion, and establishing self-sufficient local economies. In 2013, the government enacted the 'Special Act on Promotion of and Support for Urban Regeneration' to promote urban regeneration policies for the rehabilitation of old inner-city neighborhoods. The urban regeneration plan system consists of basic principles at the national level, strategic plans at the city levels, and action plans at the local levels [24]. As a strategic plan and action plan, local governments have recently begun to implement a variety of urban regeneration projects.

More recently, the Korean government has started to develop an urban regeneration model that encompasses the expansion of infrastructure, improvement of housings, and support for social integration. One of the critical points of this approach is to promote local resident participation in urban regeneration projects. The government encourages local residents who have a direct or indirect interest in the project to engage in project proposal, establishment of project plans, and implementation processes. This implementation can help to recognize the current needs of the projects, minimize conflicts, heighten the sense of community, and enhance mutual trust among stakeholders.

\section{Research Method}

\subsection{Study Area}

While most urban regeneration projects in South Korea have been implemented in the city of Seoul, some projects have been executed in many parts across the nation. In Busan, the second largest city in South Korea, one urban regeneration project is currently in progress. Particularly, our study area is "Amichojang", which is a small residential area located within the city of Busan. This place includes two administrative municipalities: Ami-dong and Chojang-dong. Its total area is $1.16 \mathrm{~km}^{2}$, as shown in Figure 1. 


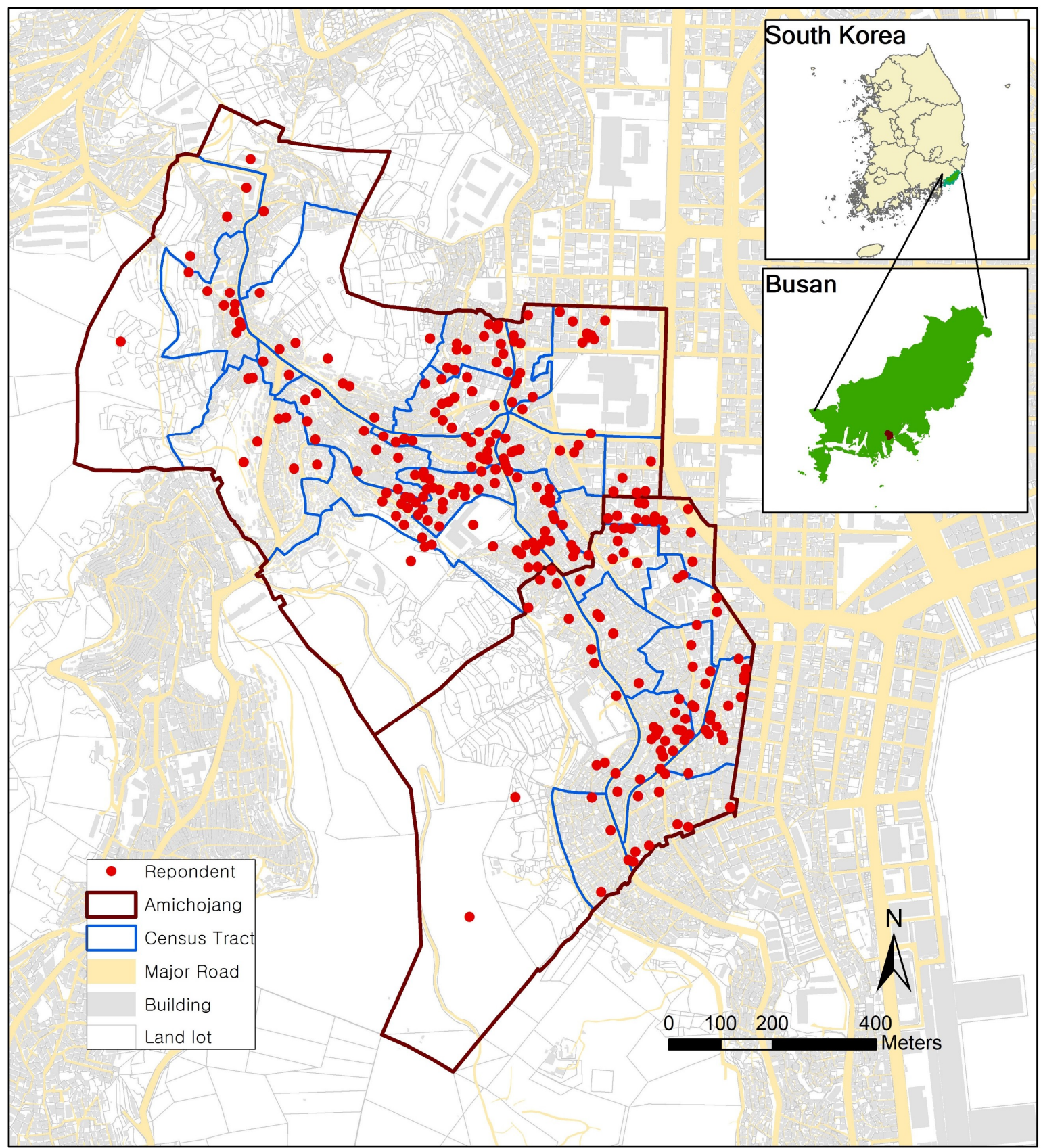

Figure 1. Study area and spatial distribution of respondents.

The number of total population in this area has substantially decreased from 46,278 to 14,727 since 1980, as shown in Table 1. Figure A1 (see Appendix A) shows the population pyramid in this area. The proportion of elderly population (age over 65 ) is $25.9 \%$ as of 2016 , which means this area faces a number of specific social and economic challenges due to population ageing. These socio-demographic trends have a number of implications for government with respect to health care, education, welfare, and economic growth. Nevertheless, there is a number of potential for economic growth in this area, such as cultural and historical resources, natural scenery, and unique characteristics of neighborhood environments. Hence, since 2014, the urban regeneration project has begun by local governments with experts, private sectors, and various stockholders for revitalizing community economies as well as improving neighborhood environments. This project includes various programs, such as housing rehabilitation, creation of public space with abandoned houses, street renovation, 
tourism development, retail revitalization, improvement of public health, physical improvement of road networks, and education of local residents.

Table 1. The number of population in the" Amichojang" area.

\begin{tabular}{ccccccccc}
\hline Year & 1980 & 1985 & 1990 & 1995 & 2000 & 2005 & 2010 & 2015 \\
\hline Population (number) & 46,278 & 41,466 & 38,364 & 32,215 & 24,654 & 19,576 & 16,598 & 14,727 \\
\hline
\end{tabular}

\subsection{Data Collection}

A survey was conducted to ascertain the attitudes and characteristics of those who live in the "Amichojang" area. In order to reduce sampling bias, we used a spatially stratified random sampling based on the census area, and the selected samples were spatially equally allocated, as shown in Figure 1. There were a variety of questions asking about individual socioeconomic characteristics such as age, income, gender, education, and employment status as well as asking residential and housing satisfaction. All respondents were asked using a five-point Likert scale (it is widely used for measuring attitude, opinions, mental dispositions, and preferences) [25], "how are you satisfied with your neighborhood environment?" 0 means "very unsatisfied" and 5 means" very satisfied". They were also asked "have you participated in the urban regeneration project that has conducted in your neighborhood?" These questions are designed to evaluate the relationship between resident participation in the urban regeneration project and residents' level of satisfaction with their neighborhood. These two are the key questions for our analysis.

Three-hundred questionnaires were delivered in person to potential respondents who live in "Amichojang". A total 292 valid surveys were returned and then were geocoded based on their specific home address as shown in Figure 1. Since spatial characteristics are important factors associated with residential satisfaction, we use the Korean micro census (i.e., "Jipgegu") to measure the living environment characteristics of each of the 292 respondents.

\subsection{Analytical Framework}

The main objective of this study is to estimate the effects of the local resident participation in urban regeneration projects on neighborhood satisfaction. This project includes urban agricultural training programs, operation of community business, and housing renovation. Such programs are designed to increase neighborhood cohesion and social capital, and thus improve resident neighborhood satisfaction. Therefore, our hypothesis is that local resident participation in urban regeneration projects is positively associated with resident neighborhood satisfaction.

As our dependent variable is measured as a five-point Likert scale, we employ ordered probit models to assess the impact of participation in the urban regeneration project on residential satisfaction. Our basic analytical model is as follows:

$$
S_{i j}=\alpha \cdot P_{i}+\beta \cdot X_{i}+\gamma \cdot L_{j}+\theta_{j}+\epsilon_{i j}
$$

where $S_{i j}$ represents residential satisfaction of individual i who lives in location $j ; P_{i}$ is a dummy variable indicates that $P_{i}$ equals one if a resident $i$ has an experience of participation in urban regeneration project and zero otherwise; $X_{i}$ represents individual socioeconomic characteristics; $L_{j}$ represents spatial characteristics of location $j ; \theta_{j}$ represents fixed-effect of location $j$; and $\epsilon_{i j}$ is error term. In order to estimate the parameters, maximum likelihood estimator is employed.

\section{Empirical Results}

\subsection{Descriptive Statistics}

Our dependent variable is neighborhood satisfaction. As shown in Table 2, the mean value of neighborhood satisfaction is 3.051, and the mean value of housing satisfaction is 3.079 . If we convert 
these values to a 100-point grading system, neighborhood satisfaction is 61 and housing satisfaction is 62 , respectively. The proportion of people who have an experience of participating in the urban regeneration project is about $24 \%$. The average age of the respondents is 55 . Among them, $72 \%$ are female, $62 \%$ have an education level above a high school degree, $76 \%$ have a job, $38 \%$ have a blue collar job, and $12 \%$ have a white collar job. The monthly average income of respondents is about $1,400,000$ won (approximately 1300 US dollars). The average distance between each respondent's house and the nearest subway station is about $500 \mathrm{~m}$. The average elevation level of each residential location is about $68 \mathrm{~m}$.

Table 2. Descriptive statistics of variables.

\begin{tabular}{llcccc}
\hline \multicolumn{1}{c}{ Variable } & \multicolumn{1}{c}{ Definition } & Mean & Std. & Min & Max \\
\hline Neighborhood Satisfaction & neighborhood satisfaction & 3.051 & 1.016 & 1 & 5 \\
Housing Satisfaction & housing satisfaction & 3.079 & 1.083 & 1 & 5 \\
Participation in Neighborhood Project & if participated = 1; or 0 & 0.236 & 0.426 & 0 & 1 \\
Neighborhood Problem & Problem caused by neighborhoods & 0.202 & 0.402 & 0 & 1 \\
Street Cleanliness & Street cleanliness & 3.582 & 1.037 & 0 & 5 \\
Female & if female = 1; male = & 0.726 & 0.447 & 0 & 1 \\
Age & respondent age & 54.829 & 15.761 & 15 & 75 \\
High School Degree & if high school degree = 1; or 0 & 0.620 & 0.486 & 0 & 1 \\
Employed & if employed = 1; unemployed =0 & 0.764 & 0.426 & 0 & 1 \\
Blue Collar Job & if blue color job = 1; or 0 & 0.387 & 0.488 & 0 & 1 \\
White Collar Job & if white color job = 1; or 0 & 0.123 & 0.329 & 0 & 1 \\
Income & monthly income & 139.897 & 122.758 & 25 & 500 \\
Subway & distance to the nearest subway station & 501.992 & 189.501 & 140 & 966 \\
Elevation & elevation level of residential location & 68.079 & 32.084 & 18 & 187 \\
\hline
\end{tabular}

Figure 2 shows histograms of the neighborhood satisfaction of respondents who have an experience of participating in the urban regeneration project. As compared to the satisfaction of all respondents, the satisfaction ratings of participants of the regeneration project are relatively higher. This means participation in the regeneration projects improve communities' cohesion and thus satisfaction. However, future analyses with more elaborated statistical models that control for other variables are necessary to evaluate the relationship between regeneration participation and neighborhood satisfaction. Therefore, as we discussed above, we examine how participation in an urban regeneration project affects neighborhood satisfaction using ordered probit models in the next section. We divided our models into two types because two important neighborhood variables, distance to the nearest subway station, and elevation level of residential location are highly correlated as shown in Appendix A.

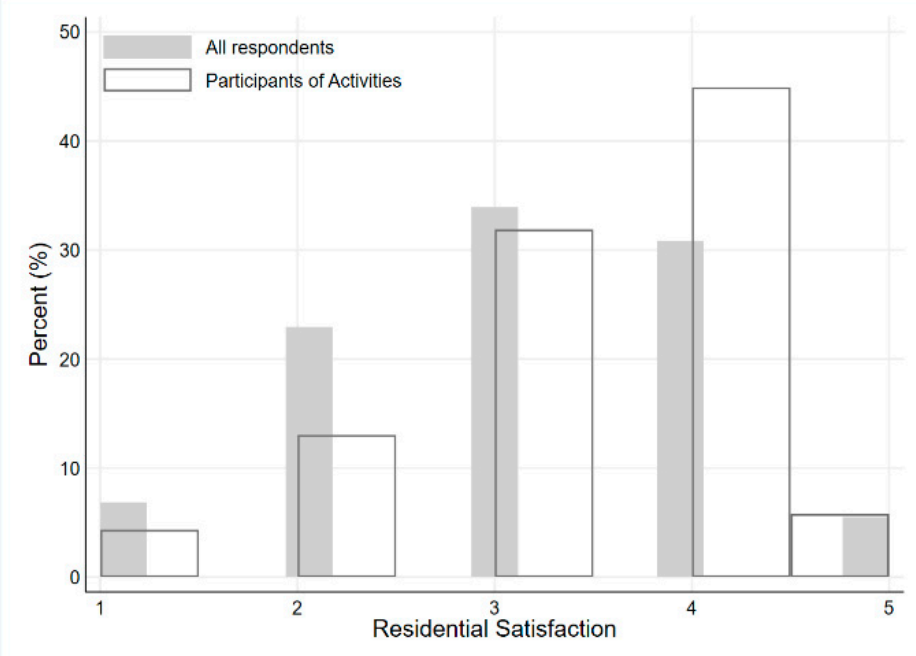

Figure 2. Histogram of residential satisfaction. 


\subsection{Regression Results}

Table 3 shows our empirical results. As we discussed above, we estimate two different models, and our hypothesis is that participation in urban regeneration projects is positively associated with neighborhood satisfaction. As shown in models 1 and 2, there is a positive relationship between participation in neighborhood projects and neighborhood satisfaction. As expected, this result suggests that participation in urban regeneration projects improves residents' neighborhood satisfaction.

Table 3. Results of ordered probit models.

\begin{tabular}{|c|c|c|}
\hline & Model (1) & Model (2) \\
\hline Participation in Urban Regeneration Project & $\begin{array}{l}0.290 * \\
(0.162)\end{array}$ & $\begin{array}{l}0.275^{*} \\
(0.162)\end{array}$ \\
\hline Housing Satisfaction & $\begin{array}{c}0.603^{* * *} \\
(0.070)\end{array}$ & $\begin{array}{c}0.603^{* * *} \\
(0.070)\end{array}$ \\
\hline Neighborhood Problems & $\begin{array}{l}-0.250 \\
(0.154)\end{array}$ & $\begin{array}{l}-0.239 \\
(0.154)\end{array}$ \\
\hline Street Cleanliness & $\begin{array}{c}0.211^{* * *} \\
(0.073)\end{array}$ & $\begin{array}{c}0.210^{* * *} \\
(0.073)\end{array}$ \\
\hline Female & $\begin{array}{c}0.172 \\
(0.161)\end{array}$ & $\begin{array}{c}0.174 \\
(0.161)\end{array}$ \\
\hline Age & $\begin{array}{c}0.000 \\
(0.005)\end{array}$ & $\begin{array}{c}0.000 \\
(0.005)\end{array}$ \\
\hline High School Degree & $\begin{array}{c}-0.384^{* *} \\
(0.183)\end{array}$ & $\begin{array}{c}-0.362 \text { ** } \\
(0.182)\end{array}$ \\
\hline Employed & $\begin{array}{c}-0.542^{* * *} \\
(0.206)\end{array}$ & $\begin{array}{c}-0.541^{* * *} \\
(0.206)\end{array}$ \\
\hline Blue Collar Job & $\begin{array}{c}0.377^{* *} \\
(0.183)\end{array}$ & $\begin{array}{c}0.371^{* *} \\
(0.183)\end{array}$ \\
\hline White Collar Job & $\begin{array}{c}0.403 \\
(0.248)\end{array}$ & $\begin{array}{c}0.382 \\
(0.248)\end{array}$ \\
\hline Income & $\begin{array}{c}0.000 \\
(0.001)\end{array}$ & $\begin{array}{c}0.000 \\
(0.001)\end{array}$ \\
\hline ln (Distance to the Nearest Subway Station) & $\begin{array}{r}-0.612 \\
(0.407)\end{array}$ & \\
\hline In (Elevation Level of Residential Location) & & $\begin{array}{c}-0.094 \\
(0.297)\end{array}$ \\
\hline Fixed-effects (Jipgegu) & Yes & Yes \\
\hline N. of Observation & 292 & 292 \\
\hline Log Likelihood & -335.285 & -336.368 \\
\hline Adj-R $R^{2}$ & 0.185 & 0.183 \\
\hline
\end{tabular}

Our control variables show expected results. Housing satisfaction is positively associated with neighborhood satisfaction. The higher the street cleanliness, the higher the residents' neighborhood satisfaction. This suggests that although urban regeneration projects are important for revitalizing declined urban neighborhoods, physical improvement such as improvement of road pavement and waste management systems should accompany the project. There is no statistical relationship between neighborhood satisfaction and residents' socioeconomic characteristics such as gender, age, and income. Respondents with education above a high school degree are less likely to be satisfied by their residential environment. One of the reasons is that people with higher educational degrees have higher criteria for their neighborhood environments, which the urban regeneration project does not meet. Likewise, people who have a job also have higher criteria for their residential environments. Both residential environmental factors such as distance to the nearest subway station and elevation have no significant relationship with neighborhood satisfaction. 


\subsection{Additional Analysis}

As shown in Table 4, the percentage of participants is different between female and male as well as age groups. Hence, in order to investigate whether gender and age differences exist in the effects of participating in the projects on neighborhood satisfaction, we provide additional evidence with estimation results. Table 5 presents the results of male and female models, respectively. Interestingly, our findings show that there are different estimation results between male and female models. Female residents who participated in the urban regeneration project are likely to be satisfied by their neighborhood, whereas male residents who participated in the same project do not feel satisfied by their neighborhood. This result suggests that female and male residents have different preferences in regards to urban regeneration projects. This may be because most of the programs in urban regeneration projects run on weekdays, so that more women are able to participate in the programs than men. Therefore, more various programs that encourage male residents to participate in the programs should be designed and implemented. Moreover, although further analysis of the effects of the specific projects on satisfaction is necessary, policy makers and planners should consider that urban regeneration projects should be carefully designed to meet the residents' specific needs. Another interesting finding is that female residents are likely to be more satisfied by their neighborhood if distance to the nearest subway station is shorter. This means that female residents are more sensitive to walking distance to the nearest public transportation than male residents.

Table 4. Participants in Urban Regeneration Project (Gender and Age group).

\begin{tabular}{lcccccc}
\hline & \multicolumn{3}{c}{ Gender Group } & \multicolumn{3}{c}{ Age Group } \\
\cline { 2 - 6 } & Male & Female & Total & $<\mathbf{6 5}$ & $\geq \mathbf{6 5}$ & Total \\
\hline Participation (no) & 66.00 & 157.00 & 223.00 & 135.00 & 88.00 & 223.00 \\
& $22.60 \%$ & $53.77 \%$ & $76.37 \%$ & $46.23 \%$ & $30.14 \%$ & $76.37 \%$ \\
Participation (yes) & 14.00 & 55.00 & 69.00 & 39.00 & 30.00 & 69.00 \\
& $4.79 \%$ & $18.84 \%$ & $23.63 \%$ & $13.36 \%$ & $10.27 \%$ & $23.63 \%$ \\
Total & 80.00 & 212.00 & 292.00 & 174.00 & 118.00 & 292.00 \\
& $27.39 \%$ & $72.61 \%$ & $100.00 \%$ & $59.59 \%$ & $40.41 \%$ & $100.00 \%$ \\
\hline
\end{tabular}

Table 5. Results of Ordered Probit Models (Gender).

\begin{tabular}{lcccc}
\hline & \multicolumn{2}{c}{ Female } & \multicolumn{2}{c}{ Male } \\
\cline { 2 - 5 } & Model (3) & Model (4) & Model (5) & Model (6) \\
\hline Participation in Neighborhood Project & $0.343^{*}$ & $0.290^{*}$ & 0.469 & 0.473 \\
& $(0.190)$ & $(0.190)$ & $(0.423)$ & $(0.423)$ \\
Housing Satisfaction & $0.583^{* * *}$ & $0.576^{* * *}$ & $1.332^{* * *}$ & $1.340^{* * *}$ \\
Neighborhood Problems & $(0.085)$ & $(0.085)$ & $(0.202)$ & $(0.203)$ \\
& -0.247 & -0.204 & -0.190 & -0.211 \\
Street Cleanliness & $(0.187)$ & $(0.186)$ & $(0.380)$ & $(0.382)$ \\
& 0.097 & 0.104 & $0.699 * *$ & $0.711^{* * *}$ \\
Age & $(0.093)$ & $(0.093)$ & $(0.191)$ & $(0.192)$ \\
& 0.005 & 0.007 & -0.006 & -0.006 \\
High School Degree & $(0.008)$ & $(0.008)$ & $(0.012)$ & $(0.012)$ \\
& $-0.572^{* *}$ & $-0.485^{* *}$ & -0.535 & -0.538 \\
Employed & $(0.236)$ & $(0.233)$ & $(0.446)$ & $(0.446)$ \\
Blue Collar Job & $-0.730^{* * *}$ & $-0.706^{* * *}$ & 0.723 & 0.771 \\
& $(0.237)$ & $(0.237)$ & $(0.662)$ & $(0.668)$ \\
White Collar Job & 0.306 & 0.298 & -0.319 & -0.372 \\
& $(0.207)$ & $(0.207)$ & $(0.669)$ & $(0.674)$ \\
Income & $0.651^{* *}$ & $0.577 *$ & -0.440 & -0.471 \\
& $(0.296)$ & $(0.296)$ & $(0.816)$ & $(0.817)$ \\
ln (Distance to the Nearest Subway Station) & 0.001 & 0.001 & -0.002 & -0.002 \\
& $(0.001)$ & $(0.001)$ & $(0.002)$ & $(0.002)$ \\
& $-1.494^{* *}$ & & -0.216 & \\
\hline
\end{tabular}


Table 5. Cont.

\begin{tabular}{lcccc}
\hline & \multicolumn{2}{c}{ Female } & \multicolumn{2}{c}{ Male } \\
\cline { 2 - 5 } & Model (3) & Model (4) & Model (5) & Model (6) \\
\hline ln (Elevation Level of Residential Location) & & -0.132 & & -0.327 \\
& & $(0.463)$ & & $(0.490)$ \\
Fixed-effects (Jipgegu) & Yes & Yes & Yes & Yes \\
N. of Observation & 212 & 212 & 80 & 80 \\
Log Likelihood & -237.623 & -240.032 & -69.765 & -69.598 \\
Adj-R & 0.203 & 0.195 & 0.377 & 0.378 \\
\hline
\end{tabular}

Note: ${ }^{* * *}, * *$, and $*$ indicate significance at the $1 \%, 5 \%$, and $10 \%$ levels, respectively; std. errors are in parentheses.

We also examine age-related differences in the impact of urban regeneration projects on neighborhood satisfaction. In Korea, many elderly people live in older town areas like this place, so it is worthwhile to investigate the preferences of different age groups in urban regeneration projects. We therefore divided all respondents into age groups of over 65 and under 65 . As shown in Table 6, our results show that there are different effects of participating in urban regeneration projects on neighborhood satisfaction. Specifically, there is no significant effect of participation on satisfaction in the elderly group, whereas there are significantly positive effects of participation on neighborhood satisfaction in the younger age group. Elderly people are likely to be more satisfied in their neighborhoods than the younger age group if street cleanliness is better.

Table 6. Results of Ordered Probit Models (Age).

\begin{tabular}{|c|c|c|c|c|}
\hline & \multicolumn{2}{|c|}{ Age $<65$} & \multicolumn{2}{|c|}{ Age $\geq 65$} \\
\hline & Model (7) & Model (8) & Model (9) & Model (10) \\
\hline Participation in Neighborhood Project & $\begin{array}{c}0.543 * * \\
(0.241)\end{array}$ & $\begin{array}{c}0.510^{* *} \\
(0.241)\end{array}$ & $\begin{array}{c}0.130 \\
(0.306)\end{array}$ & $\begin{array}{c}0.160 \\
(0.307)\end{array}$ \\
\hline Housing Satisfaction & $\begin{array}{c}0.495^{* * *} \\
(0.097)\end{array}$ & $\begin{array}{c}0.498^{* * *} \\
(0.097)\end{array}$ & $\begin{array}{c}0.847^{* * *} \\
(0.136)\end{array}$ & $\begin{array}{c}0.859 * * * \\
(0.139)\end{array}$ \\
\hline Neighborhood Problems & $\begin{array}{l}-0.333 \\
(0.209)\end{array}$ & $\begin{array}{l}-0.314 \\
(0.209)\end{array}$ & $\begin{array}{l}-0.054 \\
(0.310)\end{array}$ & $\begin{array}{c}0.015 \\
(0.318)\end{array}$ \\
\hline Street Cleanliness & $\begin{array}{c}0.123 \\
(0.096)\end{array}$ & $\begin{array}{c}0.120 \\
(0.096)\end{array}$ & $\begin{array}{c}0.412 * * * \\
(0.153)\end{array}$ & $\begin{array}{c}0.407^{* * *} \\
(0.154)\end{array}$ \\
\hline Female & $\begin{array}{l}-0.128 \\
(0.221)\end{array}$ & $\begin{array}{c}-0.132 \\
(0.221)\end{array}$ & $\begin{array}{c}0.567 \\
(0.350)\end{array}$ & $\begin{array}{l}0.662 * \\
(0.356)\end{array}$ \\
\hline Age & $\begin{array}{l}-0.012 \\
(0.009)\end{array}$ & $\begin{array}{l}-0.011 \\
(0.008)\end{array}$ & $\begin{array}{c}0.031 \\
(0.027)\end{array}$ & $\begin{array}{c}0.032 \\
(0.027)\end{array}$ \\
\hline High School Degree & $\begin{array}{c}0.020 \\
(0.279)\end{array}$ & $\begin{array}{c}0.035 \\
(0.278)\end{array}$ & $\begin{array}{l}-0.514 \\
(0.370)\end{array}$ & $\begin{array}{l}-0.390 \\
(0.366)\end{array}$ \\
\hline Employed & $\begin{array}{c}-0.647^{* *} \\
(0.322)\end{array}$ & $\begin{array}{c}-0.668^{* *} \\
(0.322)\end{array}$ & $\begin{array}{l}-0.431 \\
(0.347)\end{array}$ & $\begin{array}{l}-0.427 \\
(0.348)\end{array}$ \\
\hline Blue Collar Job & $\begin{array}{c}0.299 \\
(0.244)\end{array}$ & $\begin{array}{l}0.293 \\
(0.244)\end{array}$ & $\begin{array}{c}0.240 \\
(0.377)\end{array}$ & $\begin{array}{c}0.311 \\
(0.381)\end{array}$ \\
\hline White Collar Job & $\begin{array}{c}0.233 \\
(0.298)\end{array}$ & $\begin{array}{c}0.207 \\
(0.297)\end{array}$ & $\begin{array}{l}1.118 \\
(0.770)\end{array}$ & $\begin{array}{l}1.068 \\
(0.772)\end{array}$ \\
\hline Income & $\begin{array}{c}0.001 \\
(0.001)\end{array}$ & $\begin{array}{c}0.001 \\
(0.001)\end{array}$ & $\begin{array}{c}0.001 \\
(0.002)\end{array}$ & $\begin{array}{c}0.001 \\
(0.002)\end{array}$ \\
\hline ln (Distance to the Nearest Subway Station) & $\begin{array}{l}-0.464 \\
(0.497)\end{array}$ & & $\begin{array}{l}-0.275 \\
(1.115)\end{array}$ & \\
\hline ln (Elevation Level of Residential Location) & & $\begin{array}{l}-0.024 \\
(0.359)\end{array}$ & & $\begin{array}{c}0.895 \\
(0.857)\end{array}$ \\
\hline Fixed-effects (Jipgegu) & Yes & Yes & Yes & Yes \\
\hline N. of Observation & 174 & 174 & 118 & 118 \\
\hline Log Likelihood & -192.512 & -192.947 & -110.894 & -110.377 \\
\hline Adj- $R^{2}$ & 0.184 & 0.182 & 0.338 & 0.341 \\
\hline
\end{tabular}

Note: ${ }^{* * *}, * *$, and ${ }^{*}$ indicate significance at the $1 \%, 5 \%$, and $10 \%$ levels, respectively; std. errors are in parentheses. 


\section{Discussion and Conclusions}

One of the most obvious urban problems is physical decline in old towns and neighborhoods. While urban redevelopment strategies have long been used for improving residential environments, they have failed to maintain intangible assets such as identity, uniqueness, and sense of community. Many scholars, policy-makers, and planners have argued that urban regeneration is an alternative way to renew our declined neighborhoods and sustain our communities successfully. One of the keys to successfully facilitating urban regeneration projects is to encourage resident participation. This is because participation produces more than just outcomes.

With this perspective, we examine how resident participation in urban regeneration projects affects neighborhood satisfaction by focusing on the 'Amichojang' are located in the city of Busan, South Korea. Our empirical results from the survey data show that resident participation in this urban regeneration project is positively associated with improvement of neighborhood satisfaction. This result suggests that encouraging local residents to participate in urban regeneration projects is significant for the success of those projects. One important part of the findings is that there is variation across gender and age groups. Female and non-elderly participants (age less than 65) are likely to be satisfied by their neighborhoods, but male and elderly participants are not as likely to be satisfied by their neighborhoods. One possible reason is that the participation rates of male and elderly residents are not as relatively high, compared to female and younger residents. Thus, they have less experiences participating in urban regeneration projects. In order to encourage various demographic groups to participate in urban regeneration projects, various programs should be designed to reach specific groups. Also, as shown in Arnstein's ladder, power should be given to participants, which may autonomously result in more resident participation.

Our findings also show physical aspects, such as distance to public transportation and street cleanliness are important for improving residents' neighborhood satisfaction. This implies that although the concept of urban regeneration stresses intangible assets such as cultural heritage, community identity, cohesion, and physical elements are still significant for local residents. The physical environment of neighborhoods can enhance their uniqueness and distinctiveness because physical aspects, such as historic features and urban townscape have unique characteristics. Hence, it is suggested that improvement of intangible assets as well as physical improvement of resident environments should be implemented together in urban regeneration projects.

Overall, as we discussed in Section 2, sustainable and successful urban regeneration can be achieved by resident participation. Additionally, resident participation in urban regeneration projects also improves neighborhood satisfaction, which is empirically proved in our analysis. In this regard, our study contributes to the literature regarding participation in urban regeneration. However, one important thing we remember is that participation without redistribution of power is an empty. As Arnstein (1969) highlighted, appropriate distribution of power is one of the keys for achieving successful regeneration projects. Therefore, power should be redistributed through negotiations between residents, public officials, and stockholders. Sometimes, resident participation to the existing top-down urban regeneration projects may unnecessarily prolong the consultation period [26]. This is because multiple stakeholders who are involved in urban regeneration projects may have different expectations and different emphases on the process. As shown in our case study, different groups of gender, age, education, and income may have different preferences. Hence, to minimize conflicts between different groups and reduce negative factors in terms of time and cost, partnership between local resident, officers, politicians, professionals, and private-sectors is necessary. The appropriate partnership also can produce positive outcomes, especially in terms of residents' neighborhood satisfaction.

In spite of the important implications, our study has some limitations. First, our results are based on the specific geographic context of 'Amichojang'. Thus, our results may not be generalizable. Second, we use cross-sectional survey data, so we cannot investigate changes in neighborhood satisfaction after a long period of participation in urban regeneration projects. Our next research project will explore 
the change of participants' satisfaction with their neighborhoods. Finally, our data analysis relies on a small sample of survey data. Further analysis should be performed with more samples.

Author Contributions: E.J. carried out the survey of previous studies and wrote the draft of the manuscript. W.L. contributed to the writing and supervised the research. D.K. contributed to the research design and data analysis. E.J. and D.K. put forward the concept of this article, led the development of methodology and helped with the modifying of the manuscript. All authors contributed to write, review, correct in this manuscript.

Funding: This research was funded by [Ministry of Land, Infrastructure and Transport of Korean government] grant number [18AUDP-B077107-05].

Acknowledgments: This research was supported by a grant [18AUDP-B077107-05] through the Architecture \& Urban Development Research Program funded by Ministry of Land, Infrastructure and Transport of Korean government.

Conflicts of Interest: The authors declare no conflict of interest.

\section{Appendix}

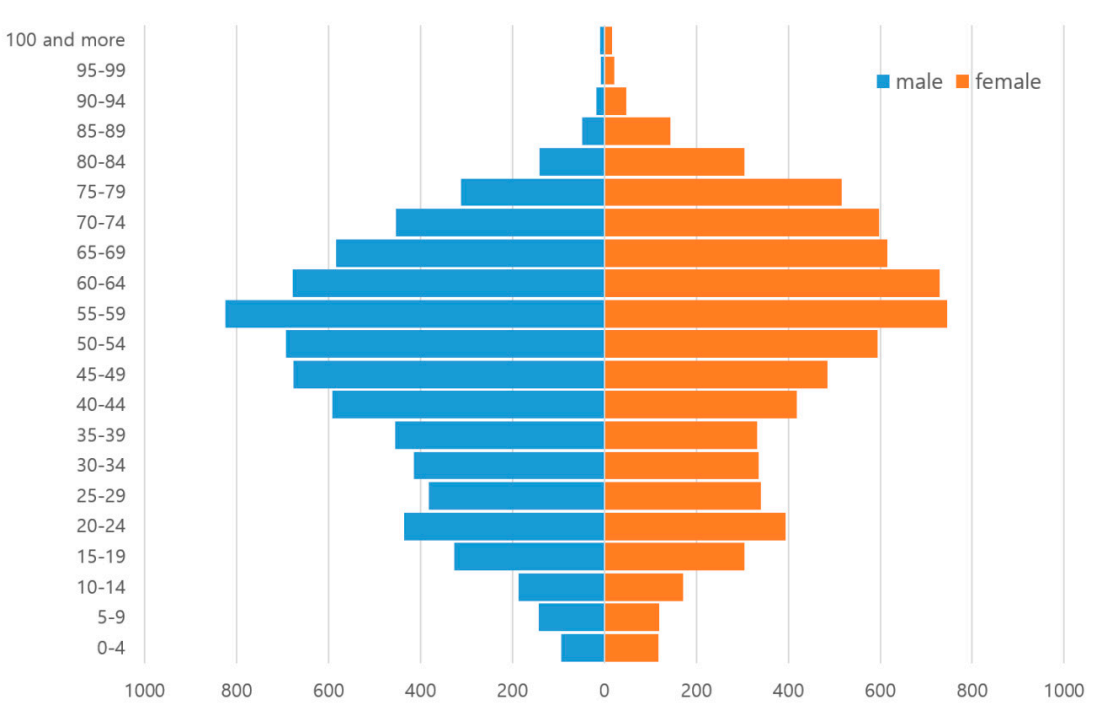

Figure A1. Population pyramid in 2015, "Amichojang".

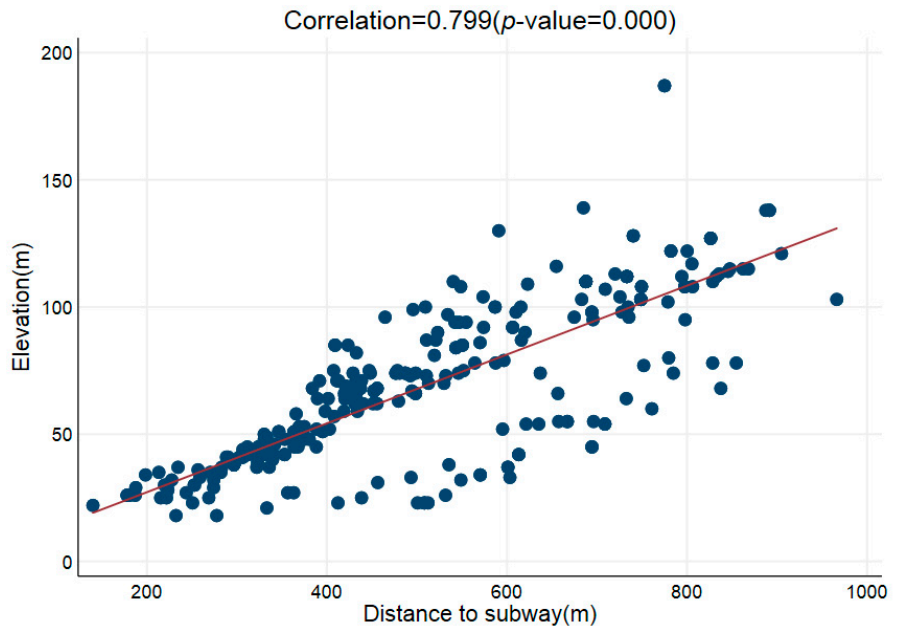

Figure A2. Correlation between distance to subway and elevation. 


\section{References}

1. Jacobs, J. The Death and Life of Great American Cities, 1st ed.; A Division of Random House: New York, NY, USA, 1961; ISBN 9780679741954.

2. Lynch, K. The Image of the City, 1st ed.; MIT Press: Cambridge, MA, USA, 1960; ISBN 9780262620017.

3. Yu, J.-H.; Kwon, H.-R. Critical success factors for urban regeneration projects in Korea. Int. J. Proj. Manag. 2011, 29, 889-899. [CrossRef]

4. Roberts, P. The evolution, definition, and purpose of urban regeneration. In Urban Regeneration: A Handbook; Roberts, P., Sykes, H., Eds.; SAGE Publications Ltd.: London, UK, 2008; Chapter 2; pp. 9-36. ISBN 9780761967170.

5. McCarthy, J. Social justice and urban regeneration policy in Scotland. Urban Res. Pract. 2010, 3, $241-256$. [CrossRef]

6. Larsen, L.; Harlan, S.; Bolin, B.; Hackett, E.; Hope, D.; Kirby, A.; Nelson, A.; Rex, T.; Wolf, S. Bonding and bridging: Understanding the relationship between social capital and civic action. J. Plan. Educ. Res. 2004, 24, 64-77. [CrossRef]

7. Pares, M.; Bonet-Marti, J.; Marti-Costa, M. Does participation really matter in urban regeneration policies? Exploring governance networks in Catalonia (Spain). Urban Aff. Rev. 2012, 48, 238-271. [CrossRef]

8. Atkinson, R. Combating social exclusion in Europe: The new urban policy challenge. Urban Stud. 2000, 37, 1037-1055. [CrossRef]

9. Couch, C.; Sykes, O.; Borstinghaus, W. Thirty years of urban regeneration in Britain, Germany and France: The importance of context and path dependency. Prog. Plan. 2011, 75, 1-52. [CrossRef]

10. Dargan, L. Participation and local urban regeneration: The case of the New Deal for Communities (NDC) in the UK. Reg. Stud. 2009, 43, 305-317. [CrossRef]

11. Parkinson, M. A new strategy for Britain's cities? Policy Stud. 1993, 14, 5-13. [CrossRef]

12. Rabbiosi, C. Urban regeneration 'from the bottom up'. City 2016, 20, 832-844. [CrossRef]

13. Hastings, A. Unravelling the process of 'Partnership' in urban regeneration policy. Urban Stud. 1996, 33, 253-268. [CrossRef]

14. Moroni, S. Rethinking the theory and practice of land-use regulation: Towards nomocracy. Plan. Theory 2010, 9, 137-155. [CrossRef]

15. Portugali, J.; Alfasi, N. An approach to planning discourse analysis. Urban Stud. 2008, 45, 251-272. [CrossRef]

16. Arnstein, S. A ladder of citizen participation. J. Am. Inst. Plan. 1969, 35, 216-224. [CrossRef]

17. Putnam, R. Bowling alone: America's declining social capital. J. Democr. 1995, 6, 65-78. [CrossRef]

18. Putnam, R. The prosperous community: Social capital and public life. Am. Prospect. 1993, 4, $35-42$.

19. Fainstein, S. The just city. Int. J. Urban Sci. 2014, 18, 1-18. [CrossRef]

20. Requena, F. Social capital, satisfaction and quality of life in the workplace. Soc. Indic. Res. 2003, 61, 331-360. [CrossRef]

21. Maass, R.; Kloeckner, C.; Lindstrom, B.; Lillefjell, M. The impact of neighborhood social capital on life satisfaction and self-rated health: A possible pathway for health promotion? Health Place 2016, 42, 120-128. [CrossRef] [PubMed]

22. Hoogerbrugge, M.; Berger, M. Neighborhood-based social capital and life satisfaction: The case of Rotterdam, The Netherlands. Urban Geogr. 2018. [CrossRef]

23. Cramm, J.; van Dijk, H.; Nieboer, A. The importance of neighborhood social cohesion and social capital for the well being of older adults in the community. Gerontologist 2012, 53, 142-150. [CrossRef] [PubMed]

24. Cho, B.; Ryu, T.; Kim, H. A study on south Korean urban regeneration plan system: For strategic urban regeneration plans. J. Digit. Contents Soc. 2017, 18, 1577-1584. [CrossRef]

25. Gob, R.; McCollin, C.; Ramalhoto, M. Ordinal methodology in the analysis of Likert scale. Qual. Quant. 2007, 41, 601-626. [CrossRef]

26. Hong, Y. Resident participation in urban renewal: Focused on Sewoon renewal promotion project and Kwun Tong town centre project. Front. Archit. Res. 2018, 7, 197-210. [CrossRef]

(C) 2018 by the authors. Licensee MDPI, Basel, Switzerland. This article is an open access article distributed under the terms and conditions of the Creative Commons Attribution (CC BY) license (http://creativecommons.org/licenses/by/4.0/). 